\title{
Seasonal hydrography and surface outflow in a fjord with a deep sill: the Reloncaví fjord, Chile
}

\author{
Manuel I. Castillo ${ }^{1,2}$, Ursula Cifuentes ${ }^{2,6}$, Oscar Pizarro ${ }^{2,3,4}$, Leif Djurfeldt ${ }^{5}$, and Mario Caceres ${ }^{1}$ \\ ${ }^{1}$ Facultad de Ciencias del Mar y de Recursos Naturales, Universidad de Valparaíso, Viña del Mar, Chile \\ ${ }^{2}$ Center for Oceanographic Research in the Eastern South Pacific (COPAS)-Sur Austral, Universidad de Concepción, \\ Concepción, Chile \\ ${ }^{3}$ Departamento de Geofísica, Universidad de Concepción, Concepción, Chile \\ ${ }^{4}$ Instituto Milenio de Oceanografía, Universidad de Concepción, Concepción, Chile \\ ${ }^{5}$ Department of Oceanography, Earth Sciences Center, Gothenburg University, Gothenburg, Sweden \\ ${ }^{6}$ Departamento de Oceanografía y Medio Ambiente, Instituto de Fomento Pesquero, Valparaíso, Chile
}

Correspondence to: Manuel I. Castillo (manuel.castillo@uv.cl)

Received: 19 September 2015 - Published in Ocean Sci. Discuss.: 29 October 2015

Revised: 9 March 2016 - Accepted: 29 March 2016 - Published: 12 April 2016

\begin{abstract}
Seasonal data on temperature, salinity, dissolved oxygen (DO) and chlorophyll, combined with meteorological and river discharge time series, were used to describe the oceanographic conditions of the Reloncaví fjord $\left(41^{\circ} 35^{\prime} \mathrm{S}\right.$, $72^{\circ} 20^{\prime} \mathrm{W}$ ). The winds in the fjord valley mainly blow downfjord during the winter, reinforcing the upper layer outflow, whereas the winds blow predominantly up-fjord during the spring and summer, contrary to the upper layer outflow. The fjord, with a deep sill at the mouth, was well stratified yearround and featured a thin surface layer of brackish water with mean salinities between $10.4 \pm 1.4$ (spring) and 13.2 \pm 2.5 (autumn). The depth of the upper layer changed slightly among the different studied seasons but remained at $4.5 \mathrm{~m}$ near the mouth. This upper layer presented a mean outflow $\left(Q_{1}\right)$ of $3185 \pm 223 \mathrm{~m}^{3} \mathrm{~s}^{-1}$, which implies a flushing time of 3 days for this layer. The vertical salt flux was $\sim 37$ tons of salt per second, similar to the horizontal salt flux observed in the upper layer. These estimates will contribute to better management of the aquaculture in this region.
\end{abstract}

\section{Introduction}

Fjords are narrow, generally deep coastal inlets associated with the advance and retreat of glaciers (Stigebrandt, 2012). Studies of these areas have been widely reported for Scandinavian and northeast Pacific fjords (Farmer and Freeland,
1983; Inall and Gillibrand, 2010), but little is known about the physical dynamics of one of world's most extensive fjord region: the austral Chilean fjords (Silva and Palma, 2008; Pantoja et al., 2011; Iriarte et al., 2014).

The austral Chilean fjord area extends from 41.5 to $55.9^{\circ} \mathrm{S}$, a length of $1700 \mathrm{~km}(\sim 40 \%$ of the total length of Chile) and an area of $2.4 \times 10^{5} \mathrm{~km}^{2}$ (Silva et al., 2011). Since early eighties, the region from 41.5 to $42^{\circ} \mathrm{S}$ has been intensively used for fish, shellfish and seaweed production. Recently, the southern limit of the aquaculture is $46^{\circ} \mathrm{S}$, and there are plans to expand to $55^{\circ} \mathrm{S}$ in 2015 (http://www. subpesca.cl). Most of the Chilean aquaculture production comes from salmon farms, which have become the fourth largest economic activity in Chile (Buschman et al., 2009). Despite the high utilization of fjords, knowledge of the physical dynamics remains limited. In fact, in the Chilean fjord region, only limited environmental data are available in both space and time (e.g., Silva and Palma, 2008). As an example, there are only preliminary studies (e.g., Dávila et al., 2002) on the impact of the freshwater supply on Chilean Patagonia circulation in regions with high river discharge (Niemeyer and Cereceda, 1984).

One of the first fjords used for salmon aquaculture in Chile was the Reloncaví fjord (centered at $41.5^{\circ} \mathrm{S}, 72.5^{\circ} \mathrm{W}$ ). Although this is one of the most studied fjords in southern Chile, oceanographic information is relatively scarce, and several questions regarding its natural and anthropogenic 
variability remain unanswered. Soto and Norambuena (2004) noted the concern about the impact of the aquaculture on the system. As an example, Valle-Levinson et al. (2007) found lower (but still above critical levels) dissolved oxygen (DO) concentrations $\left(>2 \mathrm{mLL}^{-1}\right)$ near the head of the fjord, but its variability and impact on the biology in different seasons remain unknown. In addition, in this region León-Muñoz et al. (2013) indicated the existence a significant association between the increase of surface salinity and low DO concentrations, but the variability and relationship between these parameters below $2 \mathrm{~m}$ depth remain unknown. Montero et al. (2011) made along-fjord observations that focused on seasonal variability of primary production. They did not observe DO as low as Valle-Levinson et al. (2007); thus, a detailed DO description is needed.

The mean circulation in the Reloncaví fjord suggests that the along-fjord currents have a three-layer vertical pattern: a thin $(<5 \mathrm{~m})$ outflow upper layer, a thick intermediate inflow layer $(>5$ and $<100 \mathrm{~m})$ and a weak deep $(>100 \mathrm{~m})$ outflow layer (Valle-Levinson et al., 2007; Castillo et al., 2012). This three-layer pattern could be an important structure but has only been sporadically observed because it can be masked by wind forcing, remote forcing and freshwater pulses (ValleLevinson et al., 2014).

Despite the diverse studies made in the Reloncaví fjord, many questions remain unanswered regarding its hydrographic conditions and circulation, such as the seasonal variability of the salinity and the exchanges with the area outside the fjord. Here, we present a study of the hydrographic seasonality and salinity fluxes using an extensive and highquality data set.

\section{Study area}

The Reloncaví fjord has an overall length is $55 \mathrm{~km}$ and the averaged width of $2.8 \mathrm{~km}$ (Table 1 ). It connects directly to Reloncaví sound and indirectly to Ancud gulf, which is connected to Pacific Ocean through the Chacao channel (to the north of Chiloé island) and by the Corcovado gulf (Fig. 1). There is a deep sill ( $\sim 200 \mathrm{~m}$ depth) located $15 \mathrm{~km}$ from the mouth, but this structure does not seem to be a barrier to the exchange of properties with external waters. The fjord has four sub-basins: (I) mouth-Marimeli, (II) MarimeliPuelo, (III) Puelo-Cochamó and (IV) Cochamó-Petrohue. The mean depths of the sub-basins are 440, 250, 200 and $82 \mathrm{~m}$, respectively (Fig. 1).

The main fresh water input to the fjord is through the Puelo river, which enters at the center of the fjord and delivers an annual mean discharge of $650 \mathrm{~m}^{3} \mathrm{~s}^{-1}$. Another important freshwater supply (annual mean discharge of $255 \mathrm{~m}^{3} \mathrm{~s}^{-1}$ ) is the Petrohue river (located at the head). Minor freshwater inputs are associated with the Cochamó river (annual mean of $20 \mathrm{~m}^{3} \mathrm{~s}^{-1}$ ) (Niemeyer and Cereceda, 1984) and the Canutillar hydroelectric plant $\left(75.5 \mathrm{~m}^{3} \mathrm{~s}^{-1}\right.$ annual mean) (Fig. 1).
Table 1. Topographic features of the sub-basins in the Reloncaví fjord (RF). Here, $b$ is the width, $L$ is the length, and $z$ is the depth.

\begin{tabular}{lccc}
\hline Sub-basin & $\begin{array}{c}b \\
(\mathrm{~km})\end{array}$ & $\begin{array}{c}L \\
(\mathrm{~km})\end{array}$ & $\begin{array}{c}z \\
(\mathrm{~m})\end{array}$ \\
\hline I & $2.2-4.5$ & 14 & $400-460$ \\
II & $2.3-4.2$ & 15 & $140-280$ \\
III & 3 & 16 & $180-200$ \\
IV & $1.1-1.6$ & 10 & $35-110$ \\
\hline RF mean & 2.8 & 55 & 250 \\
\hline
\end{tabular}

The fresh water input due to direct precipitation on the fjord represents only $2 \%$ of the river discharge (León-Muñoz et al., 2013), and for the water and salt balances made in this study, its contribution was considered to be balanced by evaporation.

Winds in the region exhibited large seasonal variability. North and northwest winds predominate during autumn and winter, while south and southwest winds predominate during spring and summer (Saavedra et al., 2010). The seasonal changes in the wind pattern were associated with an abrupt austral winter-spring transition observed in the temperature of the surface layer in the Reloncaví fjord (Montero et al., 2011). During winter, the along-fjord wind stress $\left(\tau_{y}\right)$ is mainly directed out of the fjord, with intensities of $<0.2 \mathrm{~N} \mathrm{~m}^{-2}$. In summer, $\tau_{y}$ is directed into the fjord, opposing the surface outflow, with intensities between 0.1 and $0.3 \mathrm{~N} \mathrm{~m}^{-2}$. Additionally, during this season $\tau_{y}$ had a clear diurnal cycle (Montero et al., 2011) probably related to the radiational tide effect (Farmer and Freeland, 1983; Rabinovich and Medvedev, 2015).

The currents near the mouth have a three-layer pattern. The thin upper outflow was relatively fast, reaching $30 \mathrm{~cm} \mathrm{~s}^{-1}$ near the surface. Below the upper layer, the intermediate inflow never exceeds $10 \mathrm{~cm} \mathrm{~s}^{-1}$. The deep layer is thick and weak $\left(\sim 1 \mathrm{~cm} \mathrm{~s}^{-1}\right)$. This third layer has been suggested to be a consequence of tidal rectification of the flow (Valle-Levinson et al., 2007) and recently has been studied in detail in different fjords in southern Chile (Valle-Levinson et al., 2014). This pattern could change seasonally between a two-layered structure during winter and a three-layered structure during spring and summer.

Additionally, there is evidence of an internal oscillation with a period of 3 days (Castillo et al., 2012). One of the most recent studies on this region (León-Muñoz et al., 2013) found a significant association between the temporal increase in near-surface $(1.5 \mathrm{~m}$ depth) salinity with lower surface DO concentrations; however, their observations did not describe the vertical structure or distribution of each parameters within the fjord. The objectives of this study were to examine and describe the seasonality of the hydrography of the Reloncaví fjord and to estimate the upper flow to obtain reliable flushing time estimations. 


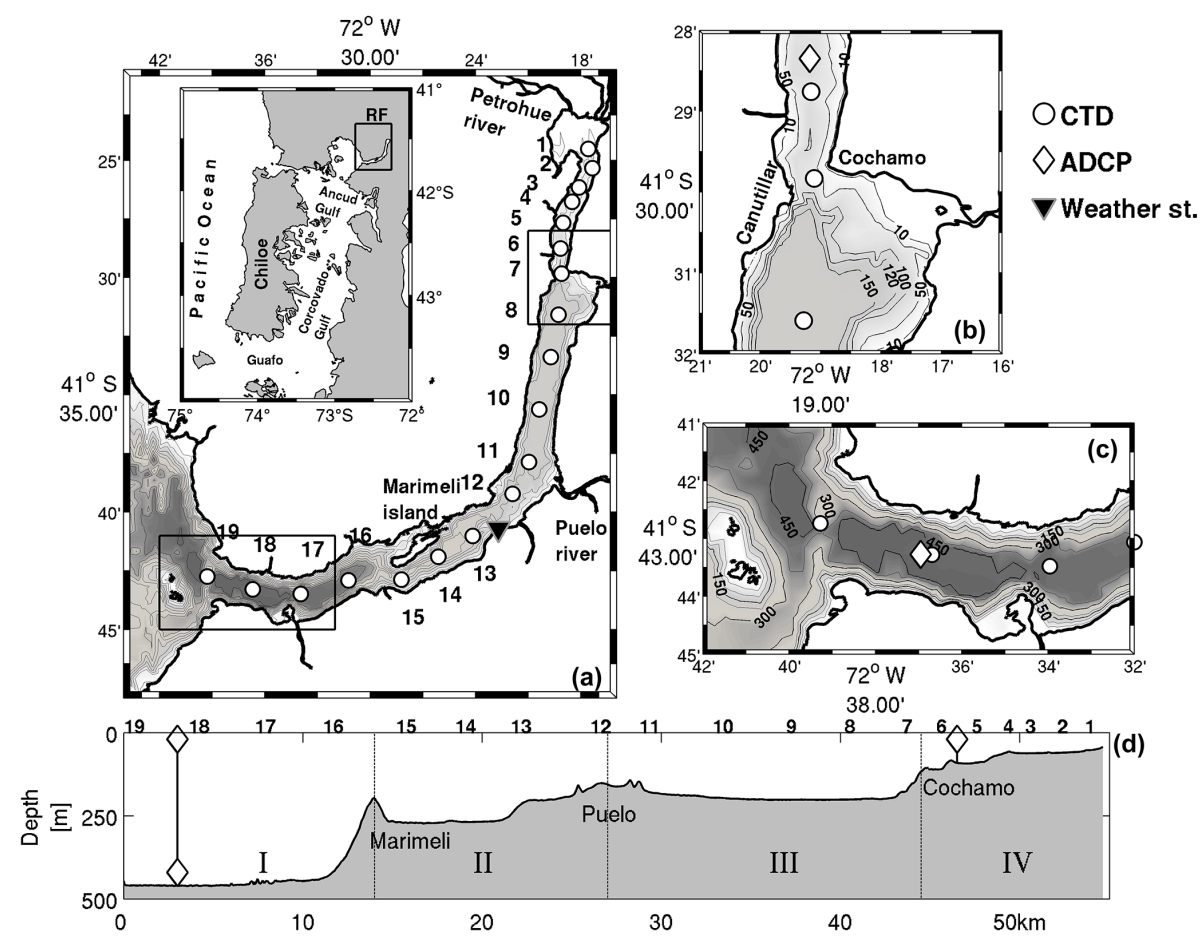

Figure 1. (a) The Reloncaví fjord region and location of the instruments. The upper left insert shows the general region. The ADCP moorings are near the mouth (ADCP). On the right, the insets show the (b) Cochamó and (c) mouth regions. The lower inset (d) shows the along-fjord bathymetry, in which the segmented lines indicate the sub-basin limits: mouth-Marimeli (I), Marimeli-Puelo (II), Puelo-Cochamó (III) and Cochamó-Petrohue (IV). The diamonds represent the location and depths of the ADCP mooring shown in panel (c).

\section{Data and methods}

\section{Discharge, meteorological, hydrographic (CTD) and current (ADCP) measurements}

Except for the acoustic Doppler current meter profiler (ADCP) current time series, most data were registered in all seasons. The representative months for each season used in this study were September to November for spring, December to February for summer, March to May for autumn and June to August for winter. A right-handed coordinate system was used for currents and surface wind stress vectors, where $z$ is positive upward and the along-fjord $y$ component was positive toward the fjord head. Consequently, the cross-fjord $x$ component was positive toward the east at the head and toward the south at the mouth.

The Puelo river discharge data were provided by Dirección General de Aguas, Chile (Dirección General de Aguas, 2015; www.dga.cl). The data are regularly collected at a station located $12 \mathrm{~km}$ up-stream of the mouth of the Puelo river (Fig. 1) and extended from January 2003 to December 2011. In this data set, gaps represented $\sim 2 \%$ of the total. Although the discharge of the Petrohue river (RPt) was not directly measured, an estimate of its runoff was obtained using the Puelo river (RP) discharge via a linear regression between both annual cycles. The annual cycle of the RP was estimated with data from 1975 to 1981 , and the annual cycle of the RPt was estimated with data from 1941 to 1982 (Niemeyer and Cereceda, 1984). Both annual cycles were highly correlated $\left(R^{2}=0.88\right)$, and $\mathrm{RPt}=0.519 \times \mathrm{RP}-68.173$. Due to the lack of data during the study period, the discharges of the Cochamó river $\left(20 \mathrm{~m}^{3} \mathrm{~s}^{-1}\right)$ and the Canutillar hydroelectric $\left(75.5 \mathrm{~m}^{3} \mathrm{~s}^{-1}\right.$ ) were considered to be constant (Niemeyer and Cereceda, 1984; www.cdec-sic.cl).

A meteorological station was installed near the Puelo river mouth (see Fig. 1). The station included sensors for wind direction and magnitude (here, wind directions are referred to by the direction from which the wind comes according to meteorological convention), solar radiation, rain and air temperature. The wind magnitude and direction sensors were installed $10 \mathrm{~m}$ a.s.l. and were set to collect data every $10 \mathrm{~min}$ from 12 June 2008 to 30 March 2011. In this data set, gaps represented only $0.04 \%$. Wind stress $(\tau)$ was calculated using a drag coefficient that is dependent on the magnitude (see Large and Pond, 1981) and a constant air density of $1.2 \mathrm{~kg} \mathrm{~m}^{-3}$.

The hydrographic data were collected using a SeaBird 25 CTD (conductivity, temperature, pressure) equipped with a SeaBird 43 dissolved oxygen sensor and a Wet-Lab/Wet-Star fluorometer (ECO-AFL). The concentration of chlorophyll $a\left(\mathrm{mg} \mathrm{m}^{-3}\right)$ from fluorescence was estimated according to the relationship provided by 
the CTD manufacturer. The CTD Oxygen/Fluorometer (CTDOF) measurements were conducted at 19 along-fjord stations (Fig. 1). The CTD measurements were conducted in transects that took between 12 and $18 \mathrm{~h}$ on 7 August 2008 (winter), 9 November 2008 (spring), 6 February 2009 (summer) and 9 June 2009 (autumn). The winter measurements only reached a depth of $\sim 50 \mathrm{~m}$ due to problems with the oceanographic winch. During those casts, the CTD was not equipped with oxygen sensor.

Current measurements were made using ADCPs. Near the mouth of the fjord, a mooring with two ADCPs was installed. The mooring included a $75 \mathrm{kHz}$ ADCP located near the bottom (450 m depth) and a $300 \mathrm{kHz}$ ADCP located at $10 \mathrm{~m}$ depth. Another mooring with a $300 \mathrm{kHz}$ at $15 \mathrm{~m}$ depth was installed near Cochamó. The objective for installing the $300 \mathrm{kHz}$ ADCP at $\sim 10 \mathrm{~m}$ depth was to obtain good velocity measurements near the surface. The instruments in both systems were programmed to measure every $10 \mathrm{~min}$ in depth cells of $1 \mathrm{~m}$. The reference depth for the velocity profiles was the surface (all data sets are available at the site of the COPAS-SUR Austral, Universidad de Concepción, 2012). Currents were decomposed into along-fjord $(v)$ and crossfjord $(u)$ components using the right-handed coordinate system mentioned above. To focus on the subtidal and subinertial variability, the along-fjord wind stress $\left(\tau_{y}\right)$ and currents $(u, v)$ were filtered using a cosine-Lanczos low-pass filter with a half-amplitude of $40 \mathrm{~h}$.

The upper volume flux $\left(Q_{1}\right)$ was estimated using the velocity profiles at the mouth and Cochamó (Fig. 1). The $Q_{1}$ was estimated according to the relationship

$Q_{1}=b \int_{z=0}^{z=v_{0}} v \mathrm{~d} z$

where $b$ is the fjord width near the surface at the mooring location ( $b$ was considered constant, despite changes in sea level of approximately $6 \mathrm{~m}$ during spring tides) and $v$ is the along-fjord velocity, which changes with depth $z$. The integration was made between the surface $(z=0)$ and the depth at which $v$ is zero $\left(z=v_{0}\right)$. The use of up-looking ADCPs implies a lack of approximately $6 \%$ ( $1 \mathrm{~m}$ for both ADCPs) of range due to side lobe effect. To estimate $v$ up to the surface, two methods of extrapolation were used: a linear method and a nearest method, similar to that used by Kirincich et al. (2005). Note that negative (positive) values of $\tau_{y}$ and $v$ indicate directions out of (into) the fjord. Similar interpretations must be performed for $Q_{1}$.

Based on the estimation of $Q_{1}$, it is possible to obtain the flushing time of the upper layer $\left(F_{t 1}\right)$ if the total volume of the upper layer $\left(V_{1}\right)$ is introduced. Thus, $F_{t 1}=V_{1} Q_{1}^{-1}$. Additionally, if the upper mean salinity $\left(S_{1}\right)$ is considered, it is possible to estimate the horizontal salt flux: $\mathrm{Fs}_{\mathrm{h}}=Q_{1} S_{1}$.

The $\mathrm{Fs}_{\mathrm{h}}$ was compared with the total vertical salt flux $\left(\mathrm{Fs}_{\mathrm{T}}\right)$ at the base of the surface layer. To obtain $\mathrm{Fs}_{\mathrm{T}}$, it is necessary

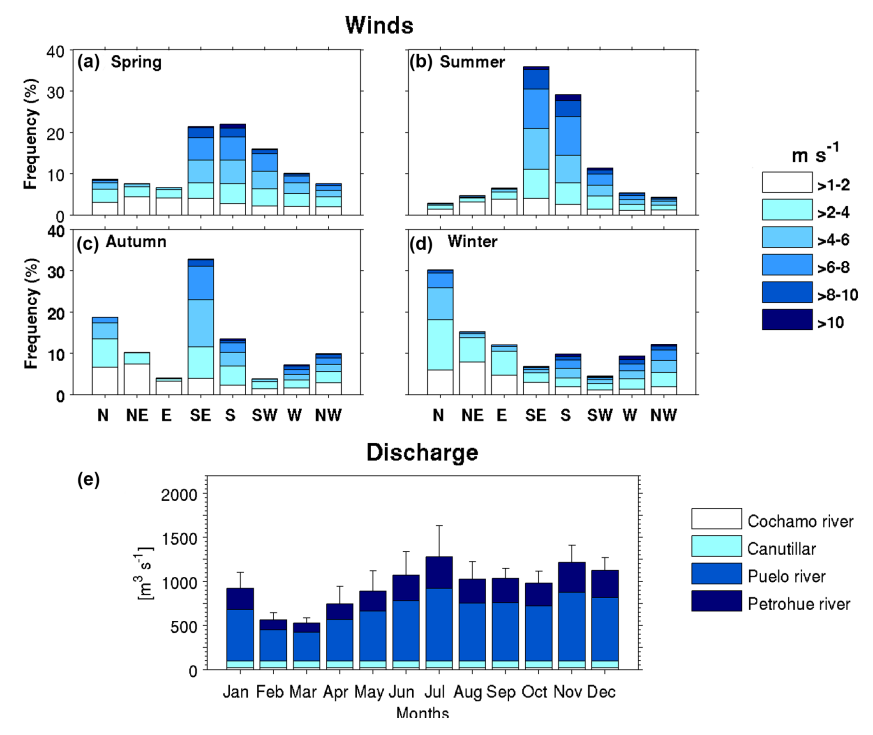

Figure 2. Seasonal variability of the wind vector in the Reloncaví fjord during the period June 2008 to March 2011. Frequency histograms of direction and magnitude for each season: (a) spring, (b) summer, (c) autumn and (d) winter. The annual cycle of the discharge into the Reloncaví fjord is shown in panel (e). Notice that the Cochamó discharge is included but is low $\left(20 \mathrm{~m}^{3} \mathrm{~s}^{-1}\right)$ compared to the other sources.

obtain the vertical salt flux $\left(\mathrm{Fs}_{\mathrm{v}}\right)$, which was estimated using $\mathrm{Fs}_{\mathrm{v}}=\kappa_{z} \partial S / \partial z$. Here, the eddy diffusivity $\left(\kappa_{z}\right)$ was estimated using the eddy viscosity $\left(A_{z}\right)$ based on the relation suggested by Pacanowski and Philander (1981), where $A_{z}=0.01(1+$ $5 R i)^{-2}+10^{-4}$ and $\kappa_{z}=A_{z}(1+5 R i)^{-1}+10^{-5}$. Here, $R i=$ $N^{2} /(\partial v / \partial z)^{2}$ is the Richardson number that was obtained from direct measurements of the buoyancy frequency $\left(N^{2}\right)$ and the vertical shear of the along-fjord currents $(\partial v / \partial z)$. $\mathrm{Fs}_{\mathrm{T}}$ was estimated by introducing the surface horizontal area $\left(A_{\mathrm{h}}\right)$ at the mean depth of the upper layer: $\mathrm{Fs}_{\mathrm{T}}=\mathrm{Fs}_{\mathrm{v}} A_{\mathrm{h}}$.

\section{Results}

\subsection{Meteorological conditions and fresh water supply}

The winds were dominantly (up to $20 \%$ ) from the southeast and south during spring, summer and autumn. In contrast, northerly winds were dominant (ca. 30\%) during winter. The strongest winds $\left(>10 \mathrm{~m} \mathrm{~s}^{-1}\right)$ were southerly and southeasterly during spring and summer (Fig. 2).

The seasonal variations in the daily cycle (in local time, LT) of the air temperature $\left({ }^{\circ} \mathrm{C}\right)$, solar radiation $\left(\mathrm{W} \mathrm{m}^{-2}\right)$, wind stress $\left(\mathrm{N} \mathrm{m}^{-2}\right)$ and wind vector $\left(\mathrm{m} \mathrm{s}^{-1}\right)$ were also analyzed (Fig. 3). The amplitudes of the daily cycles for all the variables were smaller during the winter (June-September) and larger during the spring and summer (NovemberFebruary). The air temperature exhibited a narrower range (between 6 and $8^{\circ} \mathrm{C}$ ) in winter compared with summer (12 

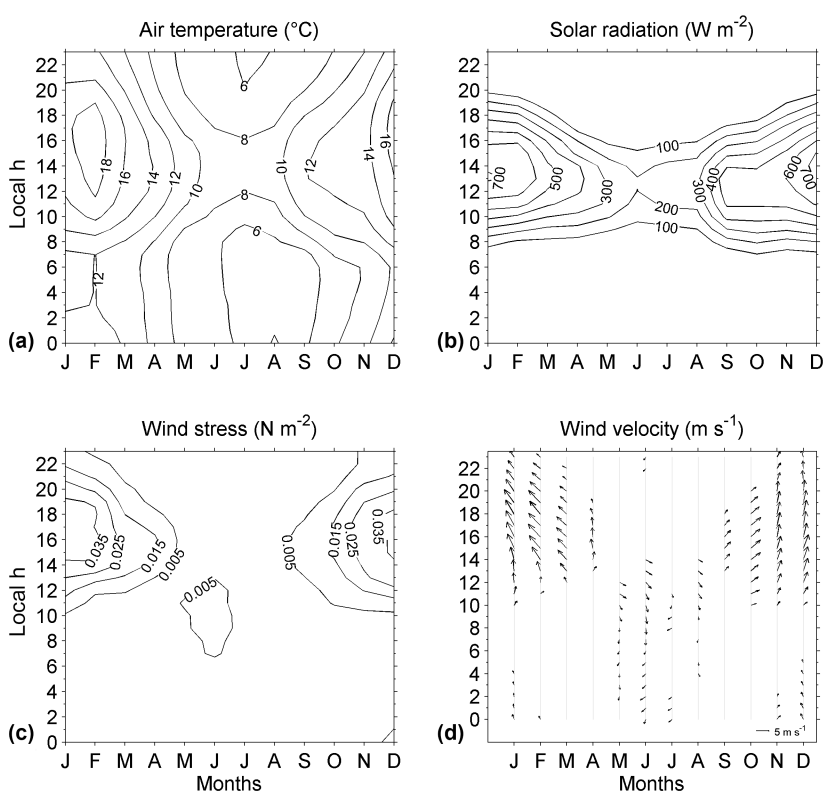

Figure 3. Seasonal variability in the daily cycle of the meteorological variables: (a) air temperature, (b) solar radiation, (c) wind stress magnitude and (d) wind velocity (meteorological convention). The $y$ axis is the local hour to be consistent with the daylight hours.

and $\left.18^{\circ} \mathrm{C}\right)$. The solar radiation was clearly related to the variations in daylight (longer in summer than in winter). Similar patterns were observed for air temperature and wind stress $(\tau)$ magnitude. In winter, the amplitude of the daily cycle of $\tau$ was nearly zero, while during spring and summer, the maximum values of $\tau$ were observed between 15:00 and 18:00 LT.

The freshwater supply due to river discharges in the Reloncaví fjord peaked during June (winter), when the mean discharge was $1400 \pm 400 \mathrm{~m}^{3} \mathrm{~s}^{-1}$ (hereafter, the symbol " \pm " indicates the standard deviation). In this region, rivers typically have a secondary discharge peak associated with spring-summer snowmelt, which was observed in November $\left(1300 \pm 300 \mathrm{~m}^{3} \mathrm{~s}^{-1}\right)$. Lower river discharges were observed during late summer (February-March) and were lower than the annual mean of the Puelo river $\left(<650 \mathrm{~m}^{3} \mathrm{~s}^{-1}\right)$.

\subsection{Seasonal hydrography: along-fjord CTD measurements}

Based on the depth of the 24 and 31 isohalines, three layers were defined to describe the hydrographic conditions in the Reloncaví fjord. The upper layer was defined between the surface and the depth of the 24 isohaline (ih24), which coincides with the depth of the maximum gradient in along-fjord salinity. The rate of increasing density with depth throughout this upper layer was rather constant, and the upper layer lacked a clear mixing layer. The mean temperature in this layer was $8.68 \pm 0.32^{\circ} \mathrm{C}$ during winter and $17.79 \pm 0.37^{\circ} \mathrm{C}$ during summer. Furthermore, the mean salinity was $10.43 \pm 1.36$ during spring and $13.18 \pm 2.47$
Table 2. Seasonal statistics of the mean depth of the upper layer and the densities of the upper and deep layers.

\begin{tabular}{lccc}
\hline & $\begin{array}{c}h_{1} \\
(\mathrm{~m})\end{array}$ & $\begin{array}{c}\rho_{1} \\
\left(\mathrm{~kg} \mathrm{~m}^{-3}\right)\end{array}$ & $\begin{array}{c}\rho_{2} \\
\left(\mathrm{~kg} \mathrm{~m}^{-3}\right)\end{array}$ \\
\hline $\begin{array}{l}\text { August } \\
\text { (winter) }\end{array}$ & $4.60 \pm 0.60$ & $1009.72 \pm 4.32$ & $1024.62 \pm 0.74$ \\
$\begin{array}{l}\text { November } \\
\text { (spring) }\end{array}$ & $4.79 \pm 0.53$ & $1007.63 \pm 5.32$ & $1024.78 \pm 0.62$ \\
$\begin{array}{l}\text { February } \\
\text { (summer) }\end{array}$ & $4.68 \pm 0.26$ & $1008.77 \pm 3.26$ & $1024.78 \pm 0.63$ \\
$\begin{array}{l}\text { June } \\
\text { (autumn) }\end{array}$ & $4.05 \pm 0.41$ & $1009.90 \pm 3.92$ & $1024.95 \pm 0.48$ \\
\hline
\end{tabular}

during autumn. Additionally, the pycnocline depth at the mouth of the fjord was observed at $1.7 \mathrm{~m}$ during winter and at $2.9 \mathrm{~m}$ during summer. Near the head of the fjord, the pycnocline reached a maximum depth of $8 \mathrm{~m}$ during winter. Seasonal changes in the mean depth of the pycnocline for the entire fjord were small: it changed from $4.05 \pm 0.41 \mathrm{~m}$ in autumn to $4.79 \pm 0.53 \mathrm{~m}$ during spring (Table 2). This suggests that the fjord maintains upper-layer stratification throughout the different seasons, even with significant changes in the river discharges and winds (Figs. 4 and 6).

The 31 isohaline (ih31) represents the upper limit for the Modified Subantarctic Water (MSAAW) located in the inland sea outside the Reloncaví fjord (Silva and Palma, 2008). The intermediate layer (at depths between the ih24 and ih31) had mean temperatures ranging from $10.22 \pm 0.14^{\circ} \mathrm{C}$ in winter to $15.29 \pm 0.48{ }^{\circ} \mathrm{C}$ in summer, which are consistent with the high degree of radiation in summer. The mean salinities ranged from $28.98 \pm 0.46$ in autumn to $29.61 \pm 0.37$ in winter. In addition, the mean depth of the ih31 shoaled from $10.97 \pm 2.49 \mathrm{~m}$ in spring to $7.96 \pm 0.84 \mathrm{~m}$ in autumn, suggesting that the water was more saline in autumn than in the other seasons (Fig. 4).

Slight changes in both temperature and salinity were observed in the deep layer (at depths $>$ ih32). The observed temperatures ranged from $10.61 \pm 0.05^{\circ} \mathrm{C}$ (winter) to $10.96 \pm 0.12{ }^{\circ} \mathrm{C}$ (autumn), and the salinities ranged from $32.27 \pm 0.16$ (winter) to $32.68 \pm 0.16$ (autumn). This pattern is consistent with the presence of more saline waters during autumn.

In general, surface waters in the Reloncaví fjord are oversaturated with respect to oxygen $\left(\mathrm{DO}>6 \mathrm{mLL}^{-1}\right)$ during spring and summer but feature lower DO values in autumn and winter. Oversaturated waters were observed between $1 \mathrm{~m}$ and $15 \mathrm{~m}$ depth in spring and between 2 and $10 \mathrm{~m}$ depth during summer. The DO values were as high as $10 \mathrm{mLL}^{-1}$ in the sub-basins III and IV near of the head (Fig. 5). In addition, waters with DO values of $<3 \mathrm{~mL} \mathrm{~L}^{-1}$ ( $\sim 50 \%$ saturation, estimated from in situ measurements) were observed near the bottom in sub-basin III during spring. These waters occupied a more extended area in the fjord basin during summer and 


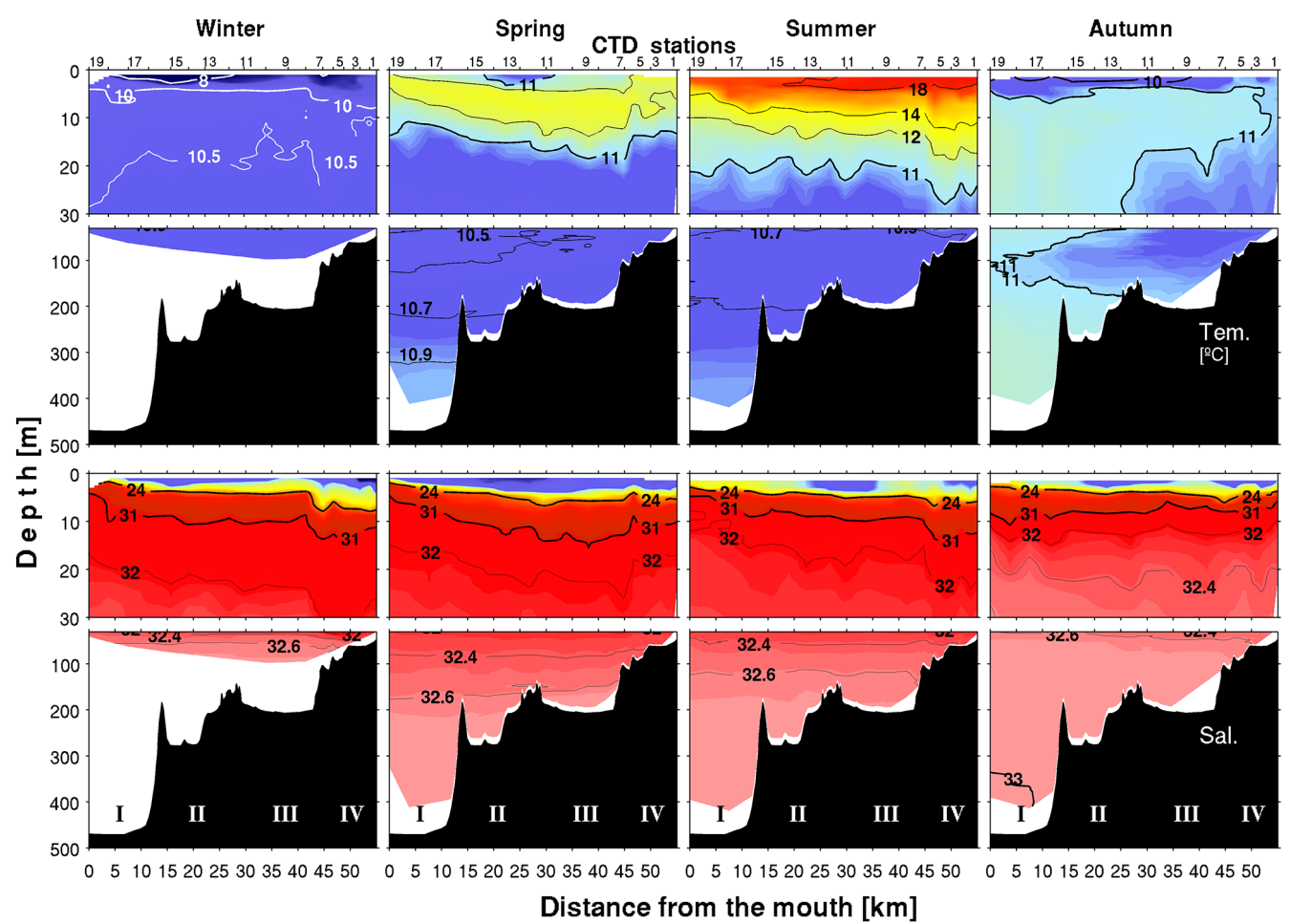

Figure 4. Along-fjord seasonal distribution of temperature (above) and salinity (below) for winter, spring, summer and autumn. The figure includes the CTD station number in the top of each panel and the sub-basins numbers below.

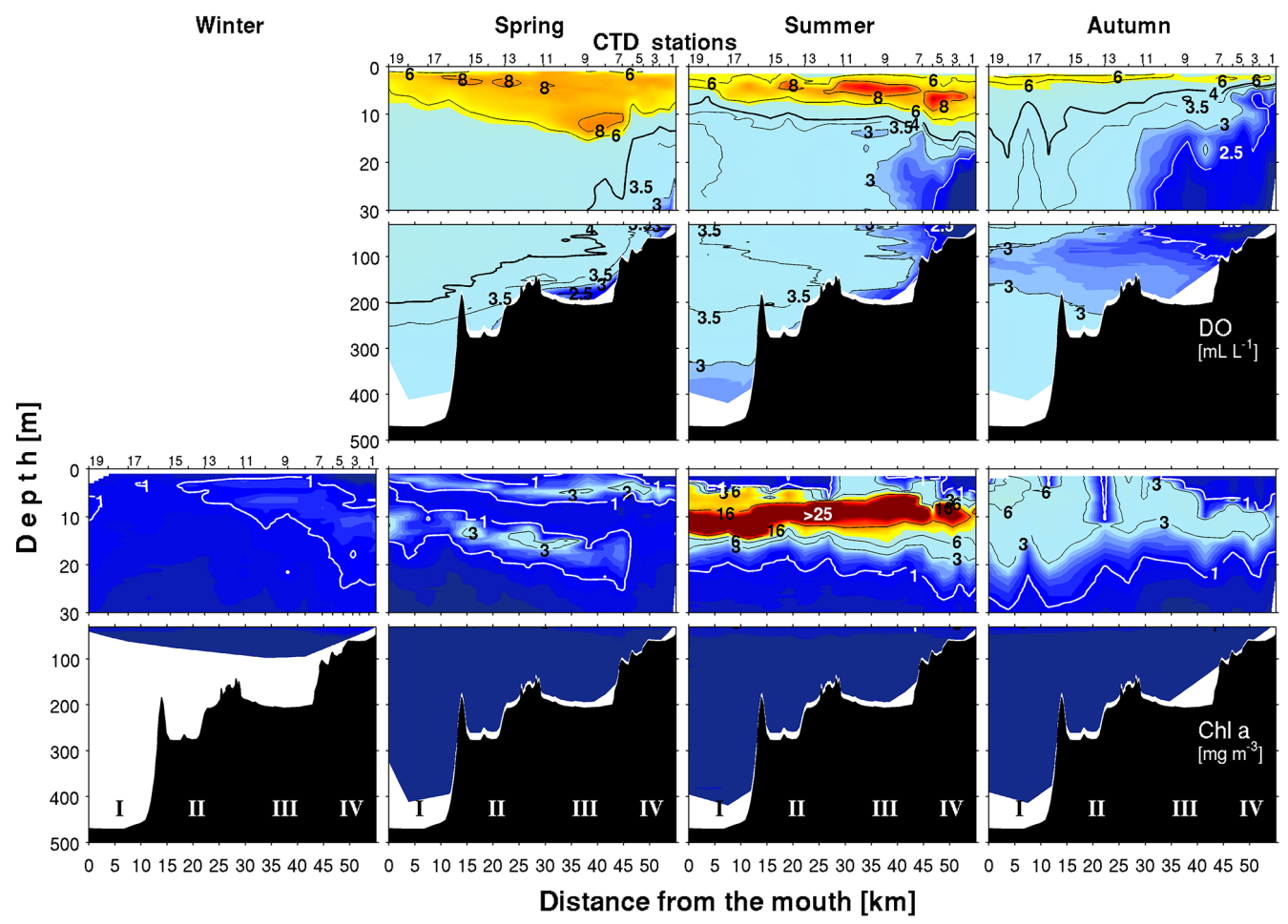

Figure 5. Along-fjord seasonal distribution of dissolved oxygen (above) and chlorophyll (below) for winter, spring, summer and autumn. The figure includes the CTD station number in the top of each panel and the sub-basins numbers below. No DO measurements were obtained during winter. 


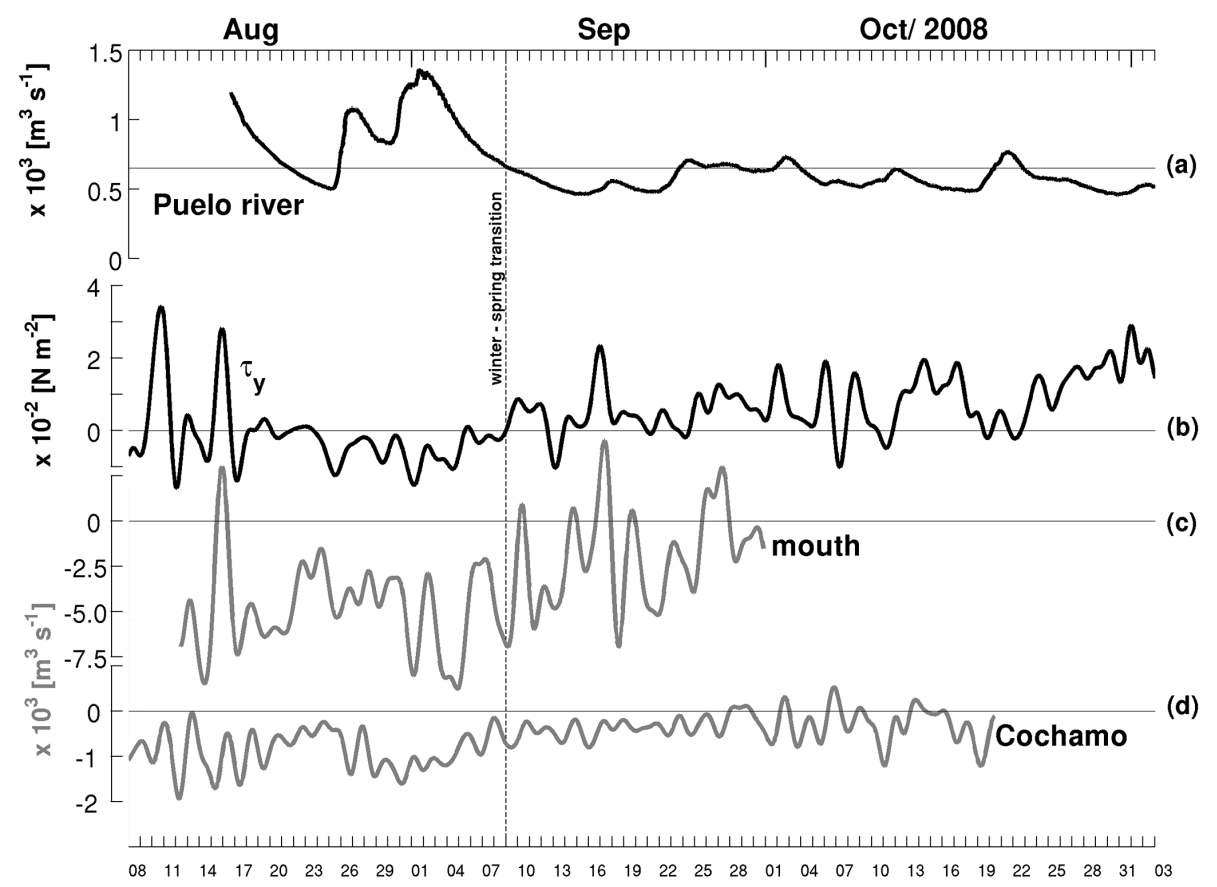

Figure 6. Low-frequency time series of the Puelo river (a), along-fjord wind stress (b), and the volume flux of the upper layer at the mouth (c) and at Cochamó (d). Note the use of a different scale for the volume flux at each location. The segmented line indicates the seasonal shift in the pattern of winds between late winter and early spring.

autumn. Waters with DO values of $<2.5 \mathrm{~mL} \mathrm{~L}^{-1}$ were observed near the bottom of sub-basins III and IV during summer and autumn.

The surface concentration of chlorophyll $a(\mathrm{Chl} a)$ was extremely low during winter (slightly greater than $0 \mathrm{mg} \mathrm{m}^{-3}$ ), and no major changes occur among the seasons. In general, water in the fjord yielded $\mathrm{Chl} a$ values of $<6 \mathrm{mg} \mathrm{m}^{-3}$ during winter, spring and autumn, with especially low Chl $a$ values $\left(\sim 1 \mathrm{mg} \mathrm{m}^{-3}\right)$ during winter. The exception was observed during summer in water at depths between 3 and $12 \mathrm{~m}$, where Chl $a$ was as high as $25 \mathrm{mg} \mathrm{m}^{-3}$ along the entire fjord. An interesting feature was observed at the entrance of subbasin IV: this high concentration was disrupted, likely due to changes in depth and width of the fjord in this region (Fig. 5).

\subsection{Variability of the upper flow}

In the period between 8 August and 9 November 2008, the filtered time series of Puelo river discharge, along-fjord wind stress $\left(\tau_{y}\right)$ and upper flows were compared (Fig. 6).

The Puelo river discharge had two contrasting periods. The first occurred at the end of August (winter) and featured high discharges $\left(>10^{3} \mathrm{~m}^{3} \mathrm{~s}^{-1}\right)$. This pattern changed in the second week of September (spring), when the discharge was between 500 and $650 \mathrm{~m}^{3} \mathrm{~s}^{-1}$ (Fig. 6a). Similarly, the $\tau_{y}$ pattern changed from negative during winter to positive during spring. This is a seasonal change from winter to spring conditions, which are then maintained during summer (see Castillo et al., 2012). In general, $\left|\tau_{y}\right|$ was $<3 \times 10^{-2} \mathrm{~N} \mathrm{~m}^{-2}$. There were three events during which this intensity was exceeded: 11 August, 15 August and 16 September. In all three of these cases, $\tau_{y}$ was oriented towards the head of the fjord (Fig. $6 \mathrm{~b}$ ).

Using the subtidal current profiles, the upper-layer flow was estimated based on a width $(b)$ of $2.9 \mathrm{~km}$ at the mouth and $1.3 \mathrm{~km}$ at Cochamó. The time series of volume flux $\left(Q_{1}\right)$ estimated with a nearest extrapolation sub-estimate in approximately $8 \%$ compared the linear extrapolation. All the results and discussion are based on the linear extrapolation.

At Cochamó, $Q_{1}$ tended to be higher during the end of winter than during early spring. The inflows were observed only during spring. In those cases, $Q_{1}<10^{3} \mathrm{~m}^{3} \mathrm{~s}^{-1}$, and the average $Q_{1}$ was $-583.31 \pm 446.43 \mathrm{~m}^{3} \mathrm{~s}^{-1}$. Additionally, $Q_{1}$ had oscillations of approximately 2-3 days, which are not present in the river discharge or wind-stress time series (Fig. 6d).

During the end of winter, the outflow reached peaks greater than $7.5 \times 10^{3} \mathrm{~m}^{3} \mathrm{~s}^{-1}$ at the mouth. $Q_{1}$ tended to decrease toward spring and rarely exceeded $5 \times 10^{3} \mathrm{~m}^{3} \mathrm{~s}^{-1}$. There were intense inflow events $\left(\sim 2.5 \times 10^{3} \mathrm{~m}^{3} \mathrm{~s}^{-1}\right)$ that were also highly correlated with wind events (in the same direction) with intensities of approximately $2 \times 10^{-2} \mathrm{~N} \mathrm{~m}^{2}$. A cross-correlation analysis between $\tau_{y}$ and $Q_{1}$ at the mouth indicated a maximum coefficient of correlation of 0.7 with a $4 \mathrm{~h}$ lag, which implies a significant relationship between the wind stress and the upper flow. Similarly to Cochamó, the 
$Q_{1}$ time series had 3-day oscillations, and these waves seem to be more evident during the early spring (Fig. 6c).

It is interesting to compare the winter and spring conditions using the mean velocity profiles and flows for each period. During the end of winter, winds were out of fjord (mean wind stress of $-0.3 \pm 7 \times 10^{-2} \mathrm{~N} \mathrm{~m}^{-2}$ ) in the same direction as the upper current with intensities larger than $-50 \mathrm{~cm} \mathrm{~s}^{-1}$. Under these conditions, $Q_{1}$ had a mean depth of $5.31 \mathrm{~m}$. During the winter, the mean $Q_{1}$ was as high as $-4045 \pm 283 \mathrm{~m}^{3} \mathrm{~s}^{-1}$ (outflow), which was $\sim 3$ times larger than the input of fresh water $(R)$ into the fjord (Fig. 7a).

In early spring, $\tau_{y}$ was oriented in an opposite (on average) direction to the upper currents (i.e., into the fjord) with a mean intensity of $1.1 \pm 5 \times 10^{-2} \mathrm{~N} \mathrm{~m}^{-2}$, which was approximately 4 times greater than in winter. These opposing winds likely reduced the surface outflow, which never exceeded $-30 \mathrm{~cm} \mathrm{~s}^{-1}$ during this period. In addition, during spring, the outflow was approximately half $\left(-2050 \pm 143 \mathrm{~m}^{3} \mathrm{~s}^{-1}\right)$ the outflow observed in winter and nearly twice as large as $R$ (Fig. 7b).

Combining the observed $Q_{1}$ and typical salinity of the upper layer during winter and spring, it was possible to obtain the horizontal salt flux associated with the upper layer $\left(\mathrm{Fs}_{\mathrm{h}}\right)$. In winter, $Q_{1}$ was $4045 \mathrm{~m}^{3} \mathrm{~s}^{-1}$, the mean salinity $\left(S_{1}\right)$ was $12.9 \mathrm{~kg}$ of salt per cubic meter $\left(\mathrm{kg} \mathrm{salt}^{-3}\right)$, and a mean density $\left(\rho_{1}\right)$ of $1009.7 \mathrm{~kg} \mathrm{~m}^{-3}$ was assumed for the upper layer. Thus, the total supply of salt associated with the upper layer during this season was $\mathrm{Fs}_{\mathrm{h}}=52.3$ tons of salt per second. During spring, the upper layer salinity was $10.5 \mathrm{~kg} \mathrm{salt} \mathrm{m}^{-3}$ $\left(\rho_{1}=1007.6 \mathrm{~kg} \mathrm{~m}^{-3}\right)$, and $Q_{1}$ was $2050 \mathrm{~m}^{3} \mathrm{~s}^{-1}$, which implies a total salt supply of $\mathrm{Fs}_{\mathrm{h}}=21.5$ tons of salt per second during this season. The relatively minor $\mathrm{Fs}_{\mathrm{h}}$ during the spring (compared with winter) was related to the high outflow and discharge differences between the seasons. A representative mean of $\mathrm{Fs}_{\mathrm{h}}$ for the entire period can be obtained from the $\mathrm{Fs}_{\mathrm{h}}$ average for winter and spring: 36.9 tons of salt per second.

To estimate the vertical salt flux $\left(\mathrm{Fs}_{\mathrm{v}}\right)$, the maximum $N^{2}$ and maximum $\partial v / \partial z$ were considered. In winter, $R i$ was $4.0\left(\kappa_{z}=1.6 \times 10^{-5} \mathrm{~m}^{2} \mathrm{~s}^{-1}\right)$, whereas in spring, $R i$ was $36.2\left(\kappa_{z}=1.1 \times 10^{-5} \mathrm{~m}^{2} \mathrm{~s}^{-1}\right)$. In addition, the maximum $\partial S / \partial z$ values were $17.4 \mathrm{~kg}$ of salt m${ }^{-4}$ in winter and $18.2 \mathrm{~kg}$ of salt $\mathrm{m}^{-4}$ in spring. The vertical salt flux $\left(\mathrm{Fs}_{\mathrm{v}}\right)$ was $2.8 \times 10^{-4} \mathrm{~kg}$ of salt $\mathrm{m}^{-2} \mathrm{~s}^{-1}$ during winter and $1.9 \times 10^{-4} \mathrm{~kg}$ of salt $\mathrm{m}^{-2} \mathrm{~s}^{-1}$ during spring. Thus, the average salt flux is $2.3 \times 10^{-4} \mathrm{~kg}$ of salt $\mathrm{m}^{-2} \mathrm{~s}^{-1}$. The total salt flux $\left(\mathrm{Fs}_{\mathrm{T}}\right)$ to the upper layer could be estimated assuming that $\mathrm{Fs}_{\mathrm{v}}$ is maintained over the horizontal area $\left(A_{\mathrm{h}}\right)$ at $5 \mathrm{~m}$ depth (which is the deeper limit for the outflow; see Fig. 7). Here, $A_{\mathrm{h}}=1.59 \times 10^{8} \mathrm{~m}^{2}$; thus, $\mathrm{Fs}_{\mathrm{T}}=3.7 \times 10^{4} \mathrm{~kg}$ of salt per second, or 37 tons of salt per second.

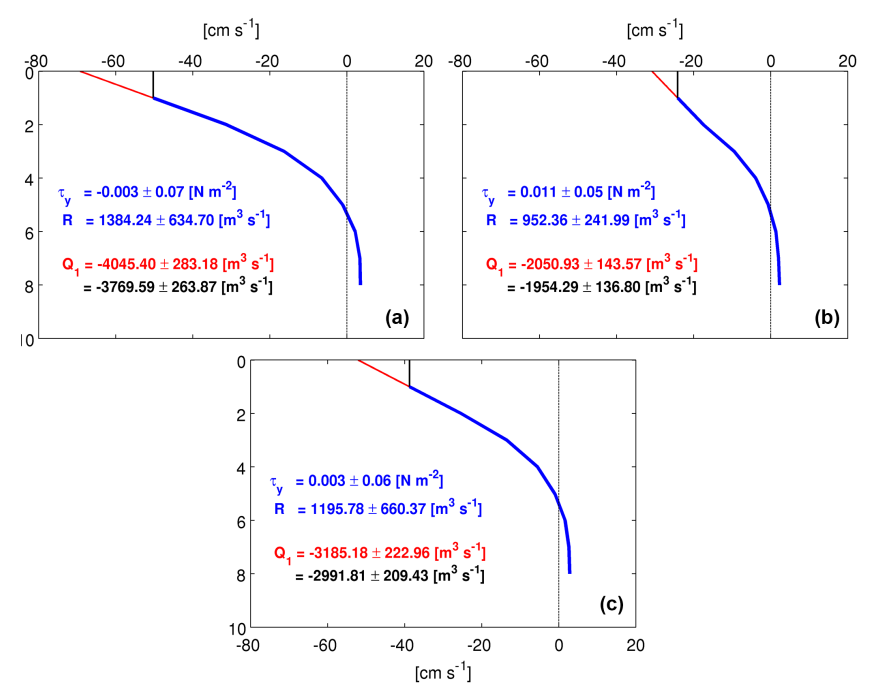

Figure 7. Mean profiles of along-fjord currents $(v)$ at the mouth for the periods of winter (a), spring (b) and for the entire period of measurement shown in Fig. 6. The blue line indicates the observed mean, which is lacking near the surface. The red and black lines indicate two different extrapolations to the surface: linear (red) and nearest (blue). The mean volume fluxes $\left(Q_{1}\right)$ obtained using the two extrapolations are included. Additionally, the averages of $\tau_{y}$ for each period and the discharge $(R)$ have been included.

\section{Discussion}

A particular feature of the Reloncavi fjord is the deep sill located at $3 \mathrm{~km}$ from the mouth (Fig. 1d). Usually, in fjords with no or deep sills, the interior density distribution and variability is closely related to the external stratification (e.g., Pedersen, 1978). The earliest efforts to describe the Reloncaví fjord were summarized by Bastén and Clement (1999), but their results are based on relatively few and sparse observations that preclude an adequate description of the seasonal variability.

\subsection{Seasonality of the hydrography and freshwater inputs}

To describe the seasonal conditions observed in the Reloncaví fjord, it is necessary describe the external conditions in the region. In the Pacific Ocean in front of Chiloé island $\left(\sim 42.5^{\circ} \mathrm{S}, 74^{\circ} \mathrm{W}\right)$, the water mass distribution indicates the presence of Subantarctic Water (SAAW) in the upper $100 \mathrm{~m}$ (salinity > 33) at the coast and farther offshore $(2000 \mathrm{~km})$. Below the SAAW and near the shore $(>10 \mathrm{~km})$, the Equatorial Subsurface Water (ESSW) is perceptible to a depth of $350 \mathrm{~m}$ (Silva et al., 2009). Only these water masses could penetrate the Guafo mouth and occupy the inland sea of Chiloé (Fig. 1). Here, the presence of several islands, sills and constrictions between the Corcovado and Ancud gulfs enhance turbulent mixing in the region. The mixing between SAAW and freshwater produces a water mass with a salinity 
between 31 and 33 and is known as the Modified Subantarctic Water (MSAAW) (Silva and Palma, 2008). The MSAAW occupies most of the interior basins of the Chilean fjord region (Pérez-Santos et al., 2014). In summer, when river discharge is limited, surface salinities greater than 33 are present off the Guafo channel (Palma et al., 2011). In winter, the coastal temperature and salinity in the Chilean fjord region appear to be controlled by the freshwater inputs (Dávila et al., 2002).

The seasonal variability in the wind in the Reloncaví fjord valley was consistent with the regional pattern observed in the south-central Chilean coast, with southerly winds during spring and summer and northerly winds during autumn and winter (e.g., Saavedra et al., 2010). During spring and summer, the alongshore wind stress promotes upwelling near the coast (Strub et al., 1998; Sobarzo et al., 2007). This process allows saltier deep water to reach the upper layer, thereby changing the near-shore hydrography.

This is also true for the Reloncaví fjord, which featured lower salinity values and temperatures during the winter (Fig. 4), when discharge presented a relatively long-term mean (8 years) of $1300 \mathrm{~m}^{3} \mathrm{~s}^{-1}$ (Fig. 2). It is worth noting that the highest salinities (> 33) in the Reloncaví fjord were observed during autumn at the bottom of sub-basin I. In addition, these waters present relatively high temperatures $\left(\sim 11^{\circ} \mathrm{C}\right)$ and low DO (Figs. 4 and 5). These results suggest that denser ocean waters may reach the Reloncaví sound in fall. Nevertheless, based on the limited spatial and temporal distribution of the data used in this study, it is not possible to know if this is a typical feature of the seasonal cycle.

In terms of DO, the volume of near-hypoxic waters (2$3 \mathrm{~mL} \mathrm{~L}^{-1}$ ) increased from spring to autumn. In autumn, more than one-third of the fjord volume exhibited near-hypoxic conditions, whereas in the spring, the fjord basin waters were oxygenated, with DO values of $>3 \mathrm{~mL} \mathrm{~L}^{-1}$ (Fig. 5). In addition, these low-oxygen conditions increased toward the head of the fjord. In fact, sub-basins III and IV are dominated by waters with DO values of $<3 \mathrm{~mL} \mathrm{~L}^{-1}$ during summer and autumn. The low-oxygen water near the head of the fjord is a condition observed in several continental fjords that are similar to the Reloncaví fjord, and these conditions are produced by the respiration of autochthonous particulate matter (Silva and Vargas, 2014). This typical low-DO at the head of the fjord has not be taken into account as selection criteria for the location of the marine concessions in the region. In the upper layer (at depths of $<20 \mathrm{~m})$, the high DO $\left(>6 \mathrm{~mL} \mathrm{~L}^{-1}\right)$ and Chl $a\left(>16 \mathrm{mg} \mathrm{m}^{-3}\right)$ values in summer suggest in situ productivity, in contrast the high $\mathrm{DO}\left(>6 \mathrm{~mL} \mathrm{~L}^{-1}\right)$ during spring were related with Chl $a$ concentrations of $\sim 1 \mathrm{mg} \mathrm{m}^{-3}$. This pattern could be due to a difference in the phytoplankton communities, which are dominated by dinoflagellates in the summer and diatoms in the spring (Montero et al., 2011). Another possibility is the advection of water with high DO values during spring, but it is not possible to address this hypothesis in this study. The relatively well-ventilated (greater than hypoxic levels) deep water observed in the Reloncaví fjord seems to be a characteristic of the southern Patagonian deep fjords of Chile (Silva and Vargas, 2014). Similar characteristics have been observed in Bradshaw and Doubtful sounds in New Zealand (Stanton and Pickard, 1981). In contrast, Scandinavian fjords commonly feature shallow sills at the mouths of the fjords, which tend to isolate the deep water and promote anoxia (Stigebrandt, 2012). As an example, the By fjord required forced oxygenation of the deep water to reduce the eutrophication of the waters (see Stigebrandt et al., 2014).

The waters in the Reloncaví fjord are dominated throughout the seasons by estuarine waters (EW) in the upper layer and MSAAW in the deep layer (Fig. 4). Recent studies have reported the presence of MSAAW in the Puyuhuapi fjord $\left(44.6^{\circ} \mathrm{S}, 72.8^{\circ} \mathrm{W}\right.$ ) (Schneider et al., 2014) and in the Martinez channel $\left(47.8^{\circ} \mathrm{S}, 73.7^{\circ} \mathrm{W}\right)$ in southern Patagonia (Pérez-Santos et al., 2014).

In the Reloncaví fjord, there is an unique connection (at the mouth) with the outer conditions and its deep sill (at $12 \mathrm{~km}$ from the mouth) does not seem to be a barrier for the intrusion of MSAAW waters, which is greatest during autumn (Figs. 4 and 5). These conditions also contribute to the propagation of remote low-frequency oscillations to the interior of the Reloncaví fjord, which have been attributed to 15-day oscillations observed in deep, along-fjord currents (Castillo et al., 2012).

\subsection{Reloncaví fjord exchanges}

One important parameter in estuarine environments is the renewal capacity of the system. Unfortunately, the ADCP measurements do not cover the entire depth range of the fjord basin, which would be necessary to obtain a complete profile of the exchanges at the mouth. However, using the shallower ADCPs, it was possible to obtain reliable estimates of the surface outflow in this location (Fig. 6).

The local winds of the Reloncaví fjord have been highly consistent with the regional pattern. The study of Montero et al. (2011) compares a pixel outside Chiloé island with the same meteorological data used here and found a significant correlation between the two data sets $(r=0.44, p<0.001)$. Furthermore, the seasonal pattern of the region (Saavedra et al., 2010) coincides with the local pattern reported in this study (Fig. 3). In addition, the wind stress was highly correlated $\left(r^{2}=0.7\right)$ with the outflow at the mouth. During winter, $\tau_{y}$ was negative, i.e., oriented in the same direction as the upper flow. Thus, $\tau_{y}$ may enhance the estuarine circulation.

The surface outflow estuarine circulation seems to be sustained even during the spring, when $\tau_{y}$ is directed against the upper flow. This differs from other estuarine system, such as the Juan de Fuca strait, where the estuarine flow tends to switch between estuarine and transient flows due to the local wind influence (Thomson et al., 2007). In the Reloncaví fjord, an along-fjord wind stress of $\geq 3 \times 10^{-2} \mathrm{~N} \mathrm{~m}^{-2}$ is able 
to balance the typical along-fjord pressure gradient (Castillo et al., 2012) and produce the observed inflows in the upper layer (Fig. 6b, c).

The estimates of the volume fluxes could help to obtain a first approximation of the water exchanges in the Reloncaví fjord. In addition, the estimation of the vertical salt flux maxima might be useful to obtain upper limits on the vertical exchange of salt along the fjord. At the mouth, the average volume flux $\left(Q_{1}\right)$ estimated from direct observations was $3185 \pm 223 \mathrm{~m}^{3} \mathrm{~s}^{-1}$. One interesting (operational) parameter is the flushing time of the upper layer $\left(F_{t 1}\right)$, which is determined by $F_{t 1}=V_{1} Q_{1}^{-1}$, where $V_{1}$ is the upper layer volume $\left(8.30 \times 10^{8} \mathrm{~m}^{3}\right)$. The flushing time of the upper layer $\left(F_{t 1}\right)$ was 3 days, which is highly consistent with the period of the oscillations observed in the time series at the mouth and Cochamó (Fig. 6).

A period of 3 days is also consistent with the natural period of oscillation in the fjord (internal seiche oscillations) reported by Castillo et al. (2012). These oscillations are mainly dominated by the first baroclinic mode (Castillo et al., 2016). The oscillations likely play a role in the internal mixing of the fjord, similar to the Gullmar fjord (Arneborg and Liljebladh, 2001), where $36 \%$ of the mixing is caused by the internal seiche. Additionally, this flushing time is similar to the $F_{t}$ estimated by Calvete and Sobarzo (2011) for the Aysén fjord $\left(45^{\circ} 16^{\prime} \mathrm{S}, 73^{\circ} 18^{\prime} \mathrm{W}\right)$; however their results were based on the fresh water fraction and a thick upper layer of $20 \mathrm{~m}$ for all the calculations, contrary to this study in which the upper layer depth was determined by the 24 isohaline depth (ih24). These flushing times estimations contrast with the 100 days estimated by Valle-Levinson et al. (2007) for the Reloncaví fjord basin, but those estimates were made based on crossfjord transects (measured on 1 day) of a towed ADCP near of the Puelo river (in the center of the fjord). Here, time series of $Q_{1}$ consider 2 months of velocity profiles based on the first reliable estimations of the upper flow in the Reloncaví fjord. In any case, these estimates must be taken carefully, and to expand the results to the fjord basin, future modeling studies must be performed to obtain the residence times of any properties in the fjord. Additionally, to study the mixing variability, future studies might include along-fjord microprofiler measurements.

The mean outflow at the mouth $\left(3185 \mathrm{~m}^{3} \mathrm{~s}^{-1}\right)$ was $\sim 6$ times the mean outflow at Cochamó $\left(583 \mathrm{~m}^{3} \mathrm{~s}^{-1}\right)$. The outflow at Cochamó represents the volume flux of subbasin IV (near the head of the fjord), which is dominated by the Petrohue river (Fig. 1). The Petrohue river discharge is estimated to be $318 \mathrm{~m}^{3} \mathrm{~s}^{-1}$. Thus, the ratio $R / Q_{1}$ was 0.55 , which implies that the outflow at Cochamó is nearly twice the freshwater input in this sub-basin.

Another way to obtain estimates of the exchanges is to use the Knudsen relation for a two-layered model. This method has been used to estimate exchange flows in Chilean fjords (e.g., Valle-Levinson et al., 2007; Calvete and So- barzo, 2011). However, the use of this relation requires the salinity to be in a steady state, which is only valid for long timescales (Geyer, 2010). Therefore, the volume flux of the upper layer is defined by $Q_{1}=R / f$. Here, $f=\left(S_{2}-S_{1}\right) / S_{2}$ is the fraction of freshwater (e.g., Dyer, 1997) and $R$ is the freshwater input to the fjord. In winter, $f$ was 0.6 , and in spring, $f$ was 0.68 . The outflow estimated using the Knudsen relation during winter (spring) at the mouth was $2293 \mathrm{~m}^{3} \mathrm{~s}^{-1}$ $\left(1403 \mathrm{~m}^{3} \mathrm{~s}^{-1}\right)$. Notice that in both seasons the outflows were underestimated. These values were $\sim 2$ times smaller than the values obtained using the mean observed flow and imply longer flushing times than observed at the mouth. In contrary, at Cochamó (sub-basin IV), the freshwater fraction $\left(f=R / Q_{1}\right)$ was 0.58 , similar to the observed fraction in sub-basin I.

These results suggest that the estimates of the water renewal of the upper layer using the Knudsen relation are only valid in sub-basin IV (upper part of the fjord) and are not valid for the entire fjord. This could have significant implications for the management of aquaculture of salmonids in the region because the salmon cages generally occupy the upper $20 \mathrm{~m}$ of the water column (Oppedal et al., 2011).

An interesting result was obtained from the estimates of the horizontal and vertical salt fluxes for the upper layer in the period between late winter and early spring (Fig. 6). The results indicate that $\sim 37$ tons of salt per second flows out from the upper layer and that the same amount of salt is supplied to the upper layer by the turbulent mixing (Fig. 7). These results suggest that the lower layer is able to sustain the output of salt from the upper layer, thereby maintaining a (nearly) steady state in terms of the amount of salt in the fjord. These results must be treated carefully and likely require more attention in future observational and numerical models studies on this region.

\section{Conclusions}

Winds in the region were consistent with the seasonal regional pattern. Northerlies dominated during winter, and southerlies dominated during summer. The strongest winds $\left(>10 \mathrm{~m} \mathrm{~s}^{-1}\right.$ ) were southerly and southeasterly in the afternoon of spring and summer. The freshwater supply had two peaks over the course of the year: the largest peak occurred in winter $\left(1400 \pm 400 \mathrm{~m}^{3} \mathrm{~s}^{-1}\right)$ during the pluvial season, and the secondary peak occurred in spring $\left(1300 \pm 300 \mathrm{~m}^{3} \mathrm{~s}^{-1}\right)$ due to snowmelt.

The pattern of the hydrography had marked seasonal changes. The water was colder during winter than summer. In the upper $10 \mathrm{~m}$, temperatures were nearly $8^{\circ} \mathrm{C}$ in winter and $18^{\circ} \mathrm{C}$ in summer. The dissolved oxygen concentration (DO) of the Reloncaví fjord was higher than $2 \mathrm{mLL}^{-1}$ in all seasons. The lowest DO was present during spring and autumn in sub-basin IV near the head of the fjord. 
The upper layer salinities $\left(S_{1}\right)$ and densities $\left(\rho_{1}\right)$ were lower during spring and higher during autumn. The change in the along-fjord pycnocline depth was minimal, which suggests that stratification was maintained throughout the seasons. The small increment of salinity of the deep layer was consistent with the intrusion of subantarctic waters modified by mixing processes that likely occurred outside the fjord.

The mean $Q_{1}$ at the mouth was $3185 \pm 223 \mathrm{~m}^{3} \mathrm{~s}^{-1}$, which was $\sim 6$ times the outflow of Cochamó $\left(583 \mathrm{~m}^{3} \mathrm{~s}^{-1}\right)$. At the mouth, the results showed large differences between the volume flux estimated using the Knudsen relation and the observed outflow. In contrast, at Cochamó, the Knudsen relation appropriately estimated the volume flux of sub-basin IV.

In the period between late winter and early spring, the upper layer had a flushing time of 3 days, which is highly consistent with the natural internal period of the fjord.

The horizontal and vertical salt fluxes were highly consistent in the period between late winter and early spring. An amount of $\sim 37$ tons of salt per second was supplied to the upper layer, and this amount of salt was very similar to the output of salt by the upper layer.

\section{Data availability}

The installation of the moorings for measuring the current, temperature and sealevel in the region was approved by the Chilean Navy through permit ${ }^{\circ}$ DS711. No specific permits were required to install the meteorological station because the location is a publicly controlled site. This study also did not involve any endangerment to species in the region.

The authors indicated that all data are available to download from a COPAS-SUR Austral website (http://www. reloncavi.udec.cl/, last access 8 April 2016). The discharge data from the rivers of Chile are available from the Dirección General del Aguas de Chile website (www.dga.cl, last access 8 April 2016). Also, all data sets can be request from the corresponding author (Manuel I. Castillo).

Acknowledgements. The authors want to thank to several graduate students from the University of Gothenburg, Sweden, and undergraduate and graduate students from the University of Concepción (UdeC), Chile, who collaborated in the fieldwork. This study is part of the $\mathrm{PFB} / 31$ COPAS-Sur Austral program and Centro de Investigación en Ecosistemas de la Patagonia by FIP2007-21 and Comité Oceanográfico Nacional CIMAR-CONA C17F 1107. Manuel I. Castillo was supported by FONDECYT grant no. 3130639 and by CONICYT-PAI no. 791220005. Finally, we want to thank the two anonymous reviewers for their observations, which helped to improve the present manuscript.

Edited by: O. Zielinski

\section{References}

Arneborg, L. and Liljebladh, B.: The internal seiches in Gullmar fjord part II - contribution to basin water mixing, J. Phys. Oceanogr., 31, 2567-2574, 2001.

Bastén, J. and Clement, A.: Oceanografía del estuario de Reloncaví, X región de Chile, Ciencia y Tecnologia del Mar, 22, 31-46, 1999.

Buschmann, A. H., Cabello, F., Young, K., Carvajal, J., Varela, D. A., and Henriquez, L.: Salmon aquaculture and coastal ecosystem health in Chile: Analysis of regulations, environmental impacts and bioremediation systems, Ocean and Coastal Management, 52, 243-249, 2009.

Calvete, C. and Sobarzo, M.: Quantification of the surface brackish water layer and frontal zones in southern Chilean fjords between Boca del Guafo ( $43^{\circ} 30^{\prime} \mathrm{S}$ ) and Estero Elefantes (46 $\left.30^{\prime} \mathrm{S}\right)$, Cont. Shelf Res., 31, 162-171, 2011.

Castillo, M. I., Pizarro, O., Cifuentes, U., Ramirez, N., and Djurfeldt, L.: Subtidal dynamics in a deep fjord of southern Chile, Cont. Shelf Res., 49, 73-89, 2012.

Castillo, M.I., Pizarro, O., Ramírez, N., and Cáceres, M.: Evidence of seiche excitation in a stratified fjord in southern Chile: forcing and damping, PLOS ONE, in review, 2016.

COPAS-SUR Austral: Oceanografía del fiordo Reloncaví, Universidad de Concepción, available at: http://www.reloncavi.udec.cl/ (last access: 8 April 2016), 2012.

Dávila, P. M., Figueroa, D., and Müller, E.: Freshwater input into the coastal ocean and its relation with the salinity distribution off austral Chile (35-55 S), Cont. Shelf Res., 22, 521-534, 2002.

Dirección General de Aguas: Datos hidrológicos en tiempo real, Chile, available at: www.dga.cl (last access: 8 April 2016), 2015.

Dyer, K. R.: Estuaries: a physical introduction, John Wiley and Sons, London, UK, 140 pp., 1997.

Farmer, D. M. and Freeland, H. J.: The physical oceanography of fjords, Prog. Oceanogr., 12, 147-194, 1983.

Geyer, W. R.: Estuarine salinity structure and circulation, in: Contemporary Issues in Estuarine Physics, edited by: ValleLevinson, A., Cambridge Univ. Press, Cambridge, UK, 12-26, 2010.

Inall, M. E. and Gillibrand, P. A.: The physics of mid-latitude fjords: a review, Geological Society, London, UK, Special Publications 344, 17-33, 2010.

Iriarte, J. L., Pantoja, S., and Daneri, G.: Oceanographic Processes in Chilean Fjords of Patagonia: From small to large-scale studies, Part A, Prog. Oceanogr., 129, 1-7, 2014.

Kirincich, A., Barth, J. A., Graham, B., Menge, B. A., and Lubchenco, J.: Wind-driven inner-shelf circulation off central Oregon during summer, J. Geophys. Res., 110, C10S03, doi:10.1029/2004JC002611, 2005.

Large, W. G. and Pond, S.: Open-ocean momentum flux measurements in moderate to strong winds, J. Phys. Oceanogr., 11, 324336, 1981.

León-Muñoz, J., Marcé, R., and Iriarte, J. L.: Influence of hydrological regime of an Andean river on salinity, temperature and oxygen in a Patagonia fjord, Chile, New Zeal. J. Mar. Fresh, 47, 515-528, 2013.

Montero, P., Daneri, G., González, H. E., Iriarte, J. L., Tapia, F. J., Lizárraga, L., Sanchez, N., and Pizarro, O.: Seasonal variability of primary production in a fjord ecosystem of the Chilean Patag- 
onia: Implications for the transfer of carbon within pelagic food webs, Cont. Shelf Res., 31, 202-215, 2011.

Niemeyer, H. and Cereceda, P.: Hidrografía, Geografía de Chile, Instituto Geográfico Militar, Santiago, Chile, 313 pp., 1984.

Oppedal, F., Dempster, T., and Stien, L. H.: Environmental drivers of Atlantic salmon behavior in sea-cages: a review, Aquaculture, 311, 1-18, 2011.

Pacanowski, R. C. and Philander, S. G. H.: Parameterization of vertical mixing in numerical models of the tropical oceans, J. Phys. Oceanogr., 11, 1443-1451, 1981.

Palma, S., Silva, N., Retamal, M. C., and Castro, L.: Seasonal and vertical distributional patterns of siphonophores and medusae in the Chiloe Interior Sea, Chile, Cont. Shelf Res., 31, 260-271, 2011.

Pantoja, S., Luis Iriarte, J., and Daneri, G.: Oceanography of the Chilean Patagonia, Cont. Shelf Res., 31, 149-153, 2011.

Pedersen, B.: A brief review of present theories of fjord dynamics, in: Hydrodynamics of estuaries and fjords, edited by: Nihoul, J. J., Elsevier Oceanography Series, New York, USA, 407-422, 1978.

Pérez-Santos, I., Garcés-Vargas, J., Schneider, W., Ross, L., Parra, S., and Valle-Levinson, A.: Double-diffusive layering and mixing in Patagonian fjords, Prog. Oceanogr., 129, 35-49, 2014.

Rabinovich, A. B. and Medvedev, I. P.: Radiational tides at the southeastern coast of the Baltic Sea, Oceanology, 55, 319-326, 2015.

Saavedra, N., Müller, E., and Fopiano, A.: On the climatology of surface wind direction frequencies for the central Chilean coast, Australian Meterological and Oceanographic Journal, 60, 103$112,2010$.

Schneider, W., Pérez-Santos, I., Ross, L., Bravo, L., Seguel, R., and Hernández, F.: On the hydrography of Puyuhuapi Channel, Chilean Patagonia, Prog. Oceanogr., 129, 8-18, 2014.

Silva, N. and Palma, S. (Eds.): The CIMAR Program in the austral Chilean channels and fjords, in: Progress in the oceanographic knowledge of Chilean inner waters, from Puerto Montt to Cape Horn, Comite Oceanográfico Nacional - Pontificia Universidad Católica de Valparaíso, Valparaíso, Chile, 11-15, 2008.

Silva, N. and Vargas, C. A.: Hypoxia in Chilean Patagonian fjords, Prog. Oceanogr., 129, 62-74, 2014.

Silva, N., Haro, J., and Prego, R.: Metals background and enrichment in the Chiloe Interior Sea sediments (Chile). Is there any segregation between fjords, channels and sounds?, Estuar. Coast. Shelf S., 82, 469-476, 2009.
Silva, N., Vargas, C. A., and Prego, R.: Land-ocean distribution of allochthonous organic matter in surface sediments of the Chiloe and Aysen interior seas (Chilean Northern Patagonia), Cont. Shelf Res., 31, 330-339, 2011.

Sobarzo, M., Bravo, L., Donoso, D., Garcés-Vargas, J., and Schneider, W.: Coastal upwelling and seasonal cycles that influence the water column over the continental shelf off central Chile, Prog. Oceanogr., 75, 363-382, 2007.

Soto, D. and Norambuena, F.: Evaluation of salmon farming effects on marine systems in the inner seas of southern Chile: A largescale mensurative experiment, J. Appl. Ichthyol., 20, 493-501, 2004.

Stanton, B. R. and Pickard, G. L.: Physical oceanography of the New Zealand fjords, New Zealand Oceanographic Institute, Memoir 88, New York, USA, 37 pp., 1981.

Stigebrandt, A.: Hydrodynamics and Circulation of Fjords, in: Encyclopedia of Lakes and Reservoirs, edited by: Bengtsson, L., Herschy, R., and Fairbridge, R., Springer Netherlands, New York, USA, 327-344, 2012.

Stigebrandt, A., Liljebladh, B., Brabandere, L., Forth, M., Granmo, Å., Hall, P., Hammar, J., Hansson, D., Kononets, M., Magnusson, M., Norén, F., Rahm, L., Treusch, A. H., and Viktorsson, L.: An Experiment with Forced Oxygenation of the Deepwater of the Anoxic By Fjord, Western Sweden, AMBIO, 44, 42-54, 2014.

Strub, P. T., Mesías, J. M., Montecino, V., Rutlant, J., and Salinas, S.: Coastal ocean circulation off western South America., in: The Sea, edited by: Robinson, A. R. and Brink, K. H., John Wiley \& Sons, New York, USA, 273-313, 1998.

Thomson, R. E., Mihály, S. F., and Kulikov, E. A.: Estuarine versus transient flow regimes in Juan de Fuca Strait, J. Geophys. Res.Oceans, 112, C09022, doi:10.1029/2006JC003925, 2007.

Valle-Levinson, A., Sarkar, N., Sanay, R., Soto, D., and León, J.: Spatial structure of hydrography and flow in a Chilean fjord, Estuario Reloncaví, Estuar. Coast., 30, 113-126, 2007.

Valle-Levinson, A., Caceres, M., and Pizarro, O.: Variations of tidally driven three-layer residual circulation in fjords, Ocean Dynam., 64, 459-469, 2014. 